\title{
ESTUDO SOBRE COLHEITA DE URINA PARA CULTURA *
}

Sofia Maria Taffil Bello Valente**

VALENTE, S. M. T. B. Estudo sobre colheita de urina para cultura. Rev. Esc. Enf. USP, São Paulo, 17(3):253-274, 1983.

O presente estudo foi realizado em 30 hospitais do Municipio de São Paulo $e$ teve como objetivos: identificar $e$ categorizar os procedimentos pertinentes à colheita de urina para cultura bacteriológica. A amostragem foi estratificada $e$ a coleta de dados realizada por meio de um instrumento, preparado para observação sistemática, ligado diretamente a um sistema interpretativo das categorias "Bom", "Regular" $e$ "Deficiente", que atende a todos os procedimentos. Os resultados foram distribuidos em freqüências absolutas e relativas $e$ as conclusões foram categorizadas segundo o sistema interpretativo das categorias previamente definido e destinado ao tema abordado.

\section{INTRODUÇÃO}

\section{Definição do problema}

Os procedimentos utilizados na colheita da amostra de urina para cultura em mulheres requerem conhecimentos de anatomia, fisiologia, métodos assépticos e habilidades por parte do profissional que os executa, o que os tornam uma técnica complexa.

O cateterismo vesical já foi muito utilizado em décadas anteriores, mas estudos realizados mostraram que o mesmo acarreta vários problemas ao paciente, sendo seu uso atualmente reduzido a casos cuja indicação se faz indispensável. Ultimamente é indicado o método de jato-médio para a colheita das amostras de urina para cultura.

\section{Revisão da literatura}

Em instituições de saúde, a urocultura tem por finalidade facilitar ao médico fazer ou elucidar o diagnóstico e prescrever o tratamento adequado.

MILLER et alii ${ }^{21}$ afirmam que o exame de urina constitui um recurso laboratorial de largo emprego na clínica, capaz de fornecer valiosos elementos à elucidação diagnóstica, sendo que sua cultura e a

* Dissertaçăo de Mestrado apresentada à Escola de Enfermagem da USP, 1982. (apresentação condensada).

** Enfermeira e Professora Assistente do Departamento de Enfermagem Médico-Cirúrgica da Escola de Enfermagem da USP - disciplina Enfermagem Médico-Cirúrgica. 
contagem de colônias revestem-se de enorme importância, tornando-o obrigatório sempre que haja suspeita de infecção urinária. nitivo.

Para BERGER ${ }^{4}$ a urocultura é necessária para o diagnóstico defi-

OLIVEIRA \& GAMARSKI ${ }^{22}$ consideram que o diagnóstico será de infecção urinária quando houver presença real de 100.000 ou mais bactérias por milímetro (ml) de urina, provenientes do aparelho urinário. Diz-se "real", quando é afastada a probabibilidade de falsa bacteriúria, oriunda da contaminação da urina por germes provenientes da vagina, das fezes, da região periuretral ou até dos frascos de colheita mal esterilizados. Ainda em relação à contagem de 100.000 bactérias $/ \mathrm{ml}$ de urina, os autores observam que, nos casos de pacientes do sexo feminino, mesmo na urina obtida pelo método de jato-médio, a faixa de falso-positivos se localiza em torno de $15 \%$.

Para MILLER et alii ${ }^{21}$ menos de 10.000 colônias por ml de urina indica contaminação acidental da amostra, entre 10.000 e 100.000 não se pode tirar conclusões categóricas e mais de 100.000 indica infecção inequívoca. Embora os limites de 10.000 bactérias por $\mathrm{ml}$ pareçam excessivamente amplos, apenas $1 \%$ das amostras caem neles. Tais amostras devem ser consideradas como suspeitas, tornando-se necessárias nova investigações.

BEESON ${ }^{3}$, BLANDY ${ }^{5}$ e CLARCK et alii ${ }^{6}$ dizem que o cateterismo vesical, mesmo sendo um procedimento estéril, pode causar infecção porque possibilita a entrada de bactérias na bexiga através da uretra. Portanto, sugerem que este procedimento seja evitado sempre que possivel.

DESAUTELS ${ }^{8}$, HERMHOLZ ${ }^{13}$, LEVIN $^{10}$ e PYRAH ${ }^{25}$ enfatizam que os catéteres uretrais só devem ser introduzidos quando for utilizado material estéril e adotada técnica asséptica.

Segundo KUNIN et alii ${ }^{17}$, nos pacientes que são cateterizados apenas para colheita de urina, com fins laboratoriais, ou para esvaziamento da bexiga a freqüência de infecção é menor que naqueles que permanecem por um período maior de $24 \mathrm{~h}$ com sonda vesical.

PARA LAPIDES et alii ${ }^{18}$ existe um risco definido de infecção com qualquer forma de cateterização.

Os grupos que parecem ser mais susceptiveis à infecção são: mulheres antes do parto ou no puerpério, pacientes idosos ou debilitados, pacientes diabéticos e pacientes com muita urina residual na bexiga. Nesses pacientes, o risco de uma única cateterização causar infecção pode chegar a um máximo de 10 a $20 \%$, enquanto que em adultos jovens normais é de 1 a $2 \%$. De acordo com KUNIN ${ }^{17}$, a cateterização uretral deve ser evitada como procedimento de rotina para colher amostras de urina ou para esvaziar a bexiga antes do parto.

DESAUTELS ${ }^{8}$ relata que há grande número de bactérias na pele, especialmente nas áreas adjacentes ao meato uretral e que um pequeno 
número de bactérias está presente na uretra a poucos centímetros do meato.

GUZE \& BEESON ${ }^{12}$ realizaram um estudo com treze casos, nos quais introduziram um catéter na uretra, sem chegar à bexiga, mergulhando-o depois em soro fisiológico estéril; em seguida, procederam à cultura das diversas amostras e constataram: Escherichia coli + Staphylococus aureus na amostra de um, Pseudomonas aeruginosas na amostra de quatro e Escherichia coli na amostra de outros quadro. As demais amostras deram culturas negativas. Os mesmos autores, durante laparotomias, retiraram urina diretamente da bexiga e, logo após fizeram nova colheita por via uretral, por meio de catéter, com todos os cuidados assépticos; em doze pacientes, todas as colheitas feitas diretamente na bexiga deram urina estéril; na urina colhida por cateterização, quatro deram crescimento de germes (três de Escherichia coli e um de Pseudomonas aeruginosas), mostrando ser flagrante a contaminação.

SADI et alii ${ }^{26}$ citam que cerca de $70 \%$ das infecções no aparelho urinário são provocadas por bacilos Gram-Negativos, principalmente Escherichia coli, Proteus vulgaris e Pseudomonas aeruginosas e pelos cocos Gram-Positivos, principalmente os estafilococos e estreptococos.

OLIVEIRA \& GAMARSKI ${ }^{22}$ chamam a atenção para fatores predisponentes à infecção urinária na mulher, dizendo que a incidência é 10 vezes maior nas mulheres que nos homens, provavelmente, devido ao fato de a uretra feminina ser curta e próxima da reto e também em decorrência das relações sexuais.

DESAUTELS ${ }^{8}$ comprovou as seguintes causas de infecção associadas ao uso do catéter: limpeza inadequada do meato urinário; contaminação de qualquer parte do catéter; trauma ou necrose da uretra pela pressão do meato devido a um catéter de calibre inadequado; entrada de bactérias na bexiga levadas pelo catéter através da uretra.

Para SADI et alii ${ }^{26}$ as vias de propagação mais comuns da infecção no sistema urogenital, são as ascendentes, através da uretra e dos ureteres, principalmente em mulheres adultas e em meninas. Segundo os autores, isto pode acontecer na vigência de processos obstrutivos do trato inferior, nos defeitos de competência da musculatura intramural do ducto uretral, o que facilita os refluxos, bem como na falta de cuidados higiênicos.

Já em 1955, KASS ${ }^{15}$ utilizou-se da colheita da amostra de urina por meio de jato-médio, como um substituto para a cateterização vesical, porque, segundo ele, os catéteres e outros instrumentos eram as maiores causas de infecções urinárias.

A prática tem mostrado que ultimamente os profissionais de enfermagem, cientes das desvantagens do cateterismo vesical, utilizam-se da técnica de jato-médio, orientando sua equipe quanto à utilização da mesma na colheita de urina para cultura bacteriológica. CLARK ?, LEVIN ${ }^{10}$ e LITTLE ${ }^{20}$ mostraram a possibiliclade de colheita asséptica do jato-médio em mulheres, apenas fazendo a limpeza da região periuretral. 
No Brasil, ANGERAMI et alii ${ }^{1,2}$ descreveram e padronizaram uma técnica de jato-médio que foi considerada adequada, uma vez que os exames bacteriológicos mostraram resultados negativos. Comprovaram, também, que para a obtenção de urina em jato é necessário preparar a paciente nos aspectos bio-psico-sociais.

\section{OBJETIVOS}

Objetivo geral. Categorizar os procedimentos efetuados na colheita de urina para cultura, em pacientes externos, do sexo feminino, com quinze anos ou mais.

Objetivos específicos. Verificar em que local dos hospitais é realizada a colheita da amostra de urina para cultura bacteriológica e qual o método utilizado; identificar os profissionais que a realizam; categorizar as condições da sala, do material existente, o manuseio do material estéril, o preparo da paciente submetida à colheita e os cuidados prestados à paciente, à amostra de urina, ao material utilizado e ao ambiente após a colheita.

\section{METODOLOGIA}

O trabalho foi desenvolvido em hospitais do Município de São Paulo, selecionados de acordo os seguintes critérios:

- hospital geral, quanto ao tipo de assistência;

- com 100 leitos ou mais;

- com unidade de pacientes externos;

- com laboratório de análises clínicas.

O universo constou de 76 hospitais do Município de São Paulo. Para delimitar o universo, utilizou-se a divisão elaborada pela Secretaria Regional de Planejamento do Governo do Estado de São Paulo, de abriJ de 1980, que divide o município em 4 regiões: Norte, Sul, Leste e Oeste.

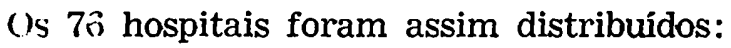

-.- Regiāo Norte: 8 hospitais; Sul: 37; Leste: 14; e Oeste: 17.

Decidiu-se pela amostragem estratificada adotando-se, para o estudo na Região Norte, uma fração amostral de $3 / 8$ (38\%); na Sul, 14/37 $(38 \%)$; na Leste, $6 / 14(43 \%)$ e na Oeste, $7 / 17(41 \%)$, perfazendo um total de 30 hospitais amostrados. Essas fraçōes amostrais foram adotadas levando-se em conta os bairros abrangidos e o número de hospitais existentes em cada região.

Foi elaborado, para coleta de dados, um instrumento (Anexo) que serviu para categorizar em "bom", "regular" e "deficiente" os cuidados prestados antes, durante e após a colheita de urina para cultura e ser utilizado de acordo com o sistema interpretativo das categorias. 


\section{PREPARO DO AMBIENTE E DO MATERIAL}

\subsection{Condições da sala de colheita da amostra de urina}

BOA - Sala privativa para colheita (ou exame) com espaço suficiente para acomodação da paciente, disposição do material e circulação da funcionária. Porta com chave. Sanitário anexo e ducha para higiene. Pia com água corrente. Uma ou mais janelas que permitam iluminação natural e arejamento do ambiente. Armários com portas para guardar material. Paredes e pisos laváveis. Boas condições de limpeza.

REGULAR - Sala com espaço suficiente para acomodação da paciente. Porta e biombos para promover a privacidade da paciente. Pia com água corrente. Sem janelas, porém, com bom sistema de iluminação artificial. Armários ou prateleiras para guardar material.

DEFICIENTE - Sala adaptada. Espaço reduzido. Sem pia e sem janelas. Пluminação e limpeza precárias e sem ventilação.

\subsection{Material utilizado na colheita da amostra de urina}

BOM - Roupas: lençol de tecido ou papel, cobertores e toalhas em quantidade de acordo com o número de pacientes atendidas diariamente; luvas entalcadas e descartáveis ou luvas comuns envelopadas e com talco, tanto umas como outras esterilizada e em quantidade e número de acordo com o movimento diário de pacientes e dos profissionais que fazem a colheita de material; recipientes para colheita da amostra da urina: próprios, de diversos tamanhos, de boca larga, com tampa e esterilizados; outros recipientes: cubas rim, cubas redondas e comadres, todos esterilizados; balde ou cesto de lixo forrado; rótulos para identificação: impressos especiais gomados (próprios para identificação); soluções anti-sépticas com rótulos de identificação e acondicionados em frascos com tampa; sondas uretrais descartáveis, esterilizadas através de raios gama ou óxido de etileno, numeração de 8 a 14, em quantidade de acordo com o movimento diário; materiais diversos: Pinça de Cheron, Pean, servente e outras; bolas de algodão, compressas e gazes estéreis; sabão neutro; papel toalha; escadinha com degraus; biombo; foco de luz; papel higiênico; escrivaninha com gavetas para colocar impressos; carrinho de curativo ou mesinha auxiliar; armários para material estéril e outros; mesa ginecológica; pacote de sondagem estéril ou bandeja descartável de cateterismo vesical.

REGULAR - Roupas: lençol de tecido, campos e toalhas, não suficientes para o número de pacientes atendidas diariamente; luvas comuns esterilizadas, não suficientes para o número de pacientes atendidas diariamente; recipientes para colheita: tubos de ensaio com tampa de algodão hidrófilo ou em rama, esterilizados, não suficientes para o número de pacientes atendidas diariamente; outros recipientes: cuba rim e redonda estéreis e comadre não esterilizada, baldes; rótulos para identificação: esparadrapo, fita gomada ou crepe; soluções anti-sépticas com rótulo de 
identificação e acondicionadas em frascos sem tampa; sondas de Nelaton descartáveis, numeração de 10 a 14 , em quantidade insuficiente para $n$ movimento diário; materiais diversos: pinça longa estéril; algodão; sabão neutro; papel toalha ou higiênico; biombo; foco de luz; escadinha; mesinha auxiliar ou bandeja; mesa ginecológica; maca ou divã com coxim; pacote de sondagem vesical estéril.

DEFICIENTE - Roupas: apenas 1 lençol ou nenhum; recipientes para colheita: tubo de ensaio ou outros sem data de esterilização; um recipiente qualquer para coletar lixo; rótulos para identificação: esparadrapo; soluções anti-sépticas: nenhuma; sondas de borracha esterilizadas no formol, apenas uma e de número não compativel com a idade da paciente; materiais diversos: maca, mesa ginecológica ou divã sem coxim; falta de material acessório necessário à colheita.

\subsection{Manuseio do material estéril}

BOM - Observação rigorosa de técnicas assépticas: utilizar a técnica de lavar e enxugar as mãos e de calçar e retirar luvas; identificar e observar a data em que o material foi esterilizado e rejeitar os materiais com data vencida; acondicionar o material estéril em armários próprios, de fácil limpeza e livre de poeiras e umidade, de preferência armários com portas; expor o material estéril o mínimo possível, evitando falar ou passar as mãos por cima dos mesmos; manusear o material por meio de pinças esterilizadas ou com as mãos enluvadas, de forma a que o mesmo permaneça estéril; manter a pinça-servente em vidro esterilizado com solução anti-séptica, devidamente rotulado e datado; manusear a pinça-servente obedecendo aos princípios de assepsia; usar pinça-servente sempre com a extremidade de apreensão voltada para baixo; proteger o frasco e a pinça-servente com tampa para evitar a contaminação; trocar por material estéril aquele que foi contaminado acidentalmente durante os procedimentos.

REGULAR - Usar o material com data de esterilização ilegivel; manusear o material sem obediência aos princípios assépticos por falta de condições materiais da instituição.

DEFICIENTE - Não observar as técnicas assépticas, havendo, conseqüentemente contaminação do material; utilizar material com data de esterilização vencida; não utilizar material estéril para o procedimento.

\section{PREPARO DA PACIENTE}

\subsection{Identificação da paciente}

BOA - Identificar a paciente pelo nome completo, número do registro ou do pedido de colheita de urina, idade e tipo de colheita de urina requisitada; preparar o rótulo com o qual será identificada a amostra de urina colhida com os dados completos (nome completo, número de registro, ou do pedido de colheita, data, horário da colheita e outras 
informações necessárias, de acordo com a rotina do hospital); anotar no frasco ou na requisição, se a paciente está fazendo uso de antibióticos e, em caso positivo, anotar o nome do mesmo.

REGULAR - Identificar a paciente apenas pelo nome e pelo número de registro ou pedido de colheita de urina; preparar o rótulo apenas com o nome e número do registro ou do pedido de colheita.

DEFICIENTE - Identificar a paciente apenas pelo nome ou não identificá-la; preparar o rótulo da amostra apenas com o número do pedido de colheita de urina ou não rotulá-la.

\subsection{Orientação da paciente}

BOA - Orientar a paciente durante a realização dos procedimentos, inclusive na auto-colheita, explicando-lhe a finalidade de cada passo da técnica, levando em consideração suas experiências anteriores; de acordo com o método utilizado pelo hospital para a colheita de amostra, orientar a paciente para que não esvazie a bexiga ou, caso esta já o tenha feito, orientá-la quanto à hidratação, para que haja volume adequado de urina no momento em que for realizada a colheita; após a colheita da amostra, orientar a paciente, se necessário, para levá-la juntamente com a requisição, ao laboratório; orientá-la sobre a data em que deverá voltar para apanhar o resultado ou retornar à consulta médica.

REGULAR - Orientar apenas em uma ou duas fases dos procedimentos; perguntar à paciente o horário de sua última micção.

DEFICIENTE - Não dar à paciente qualquer tipo de orientação; não indagar qual seu estado de hidratação e horário em que urinou, antes da colheita da amostra.

\subsection{Posição da paciente para limpeza da área genital}

BOA - Orientar a paciente para retirar a roupa de baixo e, se necessário, auxiliá-la; colocá-la em posição ginecológica (decúbito dorsal, com as pernas flexionadas e afastadas) ou outra recomendável para o caso; resguardar o seu conforto e pudor durante todo o procedimento; utilizar lençol dobrado em diagonal. $\mathrm{Na}$ auto-colheita, a paciente deve ficar de pé, e urinar no vaso sanitário com as pernas bem abertas.

REGULAR - Colocar a paciente em posição ginecológica, sem resguardo do seu conforto e pudor. $\mathrm{Na}$ auto-colheita, permitir que a paciente fique com as pernas pouco abertas. genital.

DEFICIENTE - Não posicionar a paciente para a limpeza da área

\subsection{Exposição do meato uretral externo}

BOA - Expor o meato uretral externo com os dedos indicador e polegar ou médio e polegar, protegidos com luvas, dedeiras ou gaze 
(quando é a própria paciente que colhe a amostra não há necessidade dessa proteção); os dedos utilizados nesse procedimento devem afastar os pequenos lábios lateralmente, tracionando-os em direção à sinfise pubiana, mantendo o meato uretral externo exposto até a colheita da amostra da urina.

REGULAR - Expor o meato uretral externo com os dedos indicador e polegar ou médio e polegar desprotegidos, afastando os pequenos lábios lateralmente. Não manter exposto o meato uretral externo até a colheita.

\section{DEFICIENTE - Não expor o meato uretral externo.}

\subsection{Limpeza do meato uretral externo e da área periuretral}

BOA - Utilizar uma pinça longa estéril e bolas de algodão estéreis; proceder à limpeza do meato uretral externo e área periuretral com movimentos únicos, de cima para baixo, leves, porém com pressão suficiente para deixá-los tão limpos quanto possivel; iniciar a limpeza pelo meato uretral externo; em seguida, proceder à limpeza dos lados direito e esquerdo do meato, sempre com movimentos de cima para baixo, isto é, da região pubiana para a região genital; usar uma bola de algodão embebida em solução anti-séptica para cada movimento; usar quantas bolas de algodão forem necessárias; dependendo das condições higiênicas da paciente, proceder à lavagem externa antes dos procedimentos já citados; em pacientes com secreção vaginal ou menstrual, fazer tamponamento do meato vaginal com uma bola de algodão. $\mathrm{Na}$ auto-colheita, orientar a paciente para que empregue a mesma técnica.

REGULAR - Proceder à limpeza do meato uretral externo e da área periuretral, com movimentos únicos, de cima para baixo, iniciando pelas lateriais dos pequenos lábios, e por último o meato urinário externo; utilizar poucas bolas de algodão, quando as condições higiênicas da paciente requerem melhor limpeza; não fazer tamponamento do meato vaginal em casos de secreção vaginal ou menstrual.

DEFICIENTE - Proceder à limpeza do meato urinário externo e da área periuretral com movimentos aleatórios ou não proceder à limpeza.

\section{MÉTODOS DE COLHEITA DA AMOSTRA DE URINA PARA URO- CULTURA}

BOM

Cateterismo vesical - (DUTRA et alii $\left.{ }^{10}\right)$ - Introduzir o catéter (de 4 a $5 \mathrm{~cm}$ ), diretamente no meato uretral externo, com movimentos suaves, sem forçar, até drenar urina; desprezar a primeira porção de urina na cuba rim; colher a porção do meio, diretamente em recipiente esterilizado para esse fim; colher de 2 a $8 \mathrm{ml}$ de urina se for em tubo de ensaio; caso seja utilizado outro tipo de recipiente porque o exame requer 
quantidade maior de urina, colher de 10 a $20 \mathrm{ml}$; após a colheita, retirar a sonda lentamente e encaminhar a paciente ao sanitário para esvaziar a bexiga.

Jato-médio colhido pela profissional ou ocupacional - Pedir à paciente para urinar; desprezar a primeira porção de urina na cuba rim ou na comadre e colher $o$ jato do meio no frasco esterilizado; deixar a paciente terminar de urinar.

Jato-médio colhido pela paciente - Orientar a paciente para, quando urinar, desprezar a primeira porção de urina no vaso sanitário, colher a porção do meio no recipiente esterilizado, segurando-o pelas laterais ou pela base, de forma a não contaminá-lo, entregá-lo a seguir ao profissional ou ocupacional ou colocá-lo em suporte apropriado e terminar de urinar no vaso sanitário. O profissional ou ocupacional responsável pela colheita, deve supervisionar todos os passos de procedimento.

\section{REGULAR}

Cateterismo vesical - Introduzir o catéter diretamente no meato uretral externo com movimento suave, sem forçar e depois na uretra, até drenar urina; desprezar a primeira porção em cuba rim, colher a segunda porção de urina na cuba rim estéril e depois passá-la para o recipiente próprio; retirar a sonda e dispensar a paciente.

Jato médio cothido pelo profissional ou ocupacional - Pedir à paciente para urinar; desprezar a primeira porção de urina, colher a segunda na cuba rim estéril e depois passá-la para o frasco definitivo.

Jato-médio cothido pela paciente - Pedir à paciente para urinar no vaso sanitário, desprezar a primeira parte, colher a porção do meio na cuba rim esterilizada e entregá-la à profissional ou ocupacional que a passará para o recipiente definitivo.

\section{DEFICIENTE}

Cateterismo vesical - Tentar localizar o meato uretral externo com a sonda, tocando em suas áreas adjacentes; e só depois introduzi-lo. Introduzir a sonda na vagina da paciente e, não drenada a urina, retira-a e a introduz no meato urinário. Introduzir e retirar a sonda com movimentos bruscos. Colher a urina em um recipiente e passá-la para outro sem observar técnica asséptica.

Jato-médio colhido pelo profissional ou ocupacional - Após limpar o meato urinário e a área periuretral da paciente, pedir à mesma para descer da maca ou mesa ginecológica e ficar de pé ou de cócoras para urinar. Colher a primeira ou a segunda porção de urina num recipiente e depois transferi-la para o definitivo.

Jato-médio cothido pela paciente - Oferecer a cuba rim ou recipiente estéril à paciente e encaminhá-la ao sanitário para colher uma amostra de urina. 


\section{CUIDADOS APÓS A COLHEITA DA AMOSTRA DE URINA}

\subsection{Cuidados com a paciente}

BOM - Fornecer papel higiênico à paciente para enxugar a área periuretral, se a amostra foi colhida com a mesma em decúbito dorsal ou semi-sentada na mesa ginecológica, maca ou divã; ajudá-la a descer da mesa ginecológica, maca ou divã pela escadinha, amparando-a para que se sinta segura; deixá-la à vontade ou auxiliá-la a vestir as roupas que haviam sido tiradas; esclarecê-la, se ela ainda tiver alguma dúvida sobre os procedimentos, resultados e retorno à consulta médica. Se a colheita de urina for realizada no sanitário, deixar a paciente terminar de urinar e oferecer-lhe papel higiênico para enxugar a área periuretral; pedir-lhe para lavar as mãos com sabonete e oferecer-lhe papel toalha ou similar para enxugá-las. Dar tempo à paciente para vestir a roupa.

REGULAR - Ajudar a paciente a descer da mesa de exames, amparando-a para lhe dar segurança; dar-lhe tempo para vestir a roupa.

DEFICIENTE - Não prestar cuidado algum à paciente.

\subsection{Encaminhamento da amostra ao laboratório para semeadura}

BOM - Orientar a paciente a levar a amostra, juntamente com a requisição, ao laboratório de análises do hospital, logo após a colheita, segurando o frasco na posição vertical, se a colheita for realizada no ambulatório; caso contrário, a amostra deve ser mantida em geladeira ou em local de baixa temperatura (ao abrigo do sol) e entregue ao laboratório de análises do hospital, para semeadura, antes de completar duas horas após a colheita.

REGULAR - Orientar a paciente no sentido de entregar a amostra no laboratório de análises do hospital, sem enfatizar, que deve fazê-lo o mais rápido possivel e dentro do limite de duas horas. Fazer a colheita de material e após encaminhá-la ao laboratório, observando o prazo máximo de duas horas.

DEFICIENTE - Encaminhar a amostra de urina para urocultura ao laboratório de análises, para semeadura duas horas ou mais após a colheita.

\subsection{Cuidados com o material utilizado após a colheita da amostra de urina}

BOM - Desprezar o material descartável. Deixar o material de aço inoxidável em solução detergente por 30 minutos; em seguida, lavá-lo em água corrente com escova e sabão e enxugá-lo bem; acondicioná-lo em campo limpo de algodão cru, identificá-lo e datá-lo; encaminhá-lo ao Centro de Material para esterilização. Lavar as luvas em água corrente ainda calçadas, enxugá-las e após encaminhá-las ao Centro de Material. 
REGULAR - Desprezar o material descartável. Lavar o material de aço inoxidável com água corrente e sabão, usando um trapo ou gaze; acondicioná-lo no mesmo campo de algodão cru; encaminhá-lo ao Centro de Material. Lavar as luvas em água corrente e acondicioná-las num recipiente até o final do expediente.

DEFICIENTE - Reaproveitar o material descartável; deixar o material de aço inoxidável num canto da sala, sobre a mesa ou sobre a pia, para ser lavado no fim do expediente; deixar as luvas juntamente com sondas e gazes até o final do expediente.

\subsection{Cuidados com o ambiente da sala de colheita}

BOM - Retirar os lençóis usados e forrar a mesa ginecológica, maca ou divã com lençol limpo de papel ou tecido; arrumar a mesa auxiliar ou carrinho de curativo onde ficam os anti-sépticos, pacotes de cateterismo, luvas e outros materiais necessários à colheita de urina; deixar a sala em ordem e preparada para atender à próxima paciente para colheita de urina; limpar áreas que por ventura tenham entrado em contato com a urina da paciente.

REGULAR - Retirar lençóis usados e forrar a mesa ginecológica, maca ou divã com lençol limpo de papel ou de tecido.

DEFICIENTE - Não dispensar cuidados ao ambiente da sala de colheita de urina.

\section{RESULTADOS E DISCUSSÃO}

Das 30 técnicas observadas, $87 \%$ das amostras de urina, para cultura bacteriológica, foram colhidas nos laboratórios de análises clínicas e $13 \%$ nos ambulatórios.

Do pessoal observado, $37 \%$ eram auxiliares de laboratório, $23 \%$ técnicos de laboratório, $13 \%$ atendentes de enfermagem, $10 \%$ auxiliares de enfermagem e $17 \%$ outros profissionais (bio-químicos, farmacêuticos e colhedores de material).

Os dados colhidos mostraram que as condições das salas de colheita de urina eram, em geral, regulares $(50 \%)$ e deficientes $(37 \%)$. Apenas $13 \%$ tinham condiçōes boas de acordo com a classificação deste trabalho.

Em relação ao material utilizado para a colheita da amostra de urina para urocultura, $50 \%$ foram deficientes, $27 \%$ regulares e $23 \%$ bons.

Quanto ao manuseio do material estéril verificou-se que os procedimentos foram deficientes em $57 \%$ e bons em $43 \%$ dos locais estudados. 
A identificação da paciente e da amostra de urina foram boas em $50 \%$ e regulares em $43 \%$. Apenas em $7 \%$ dos hospitais a identificação da paciente e da amostra foram deficientes.

Em $67 \%$ dos hospitais estudados, a orientação dada à paciente foi regular, em $23 \%$ deficiente e em $10 \%$ boa.

A posição da paciente para a limpeza do meato uretral externo foi boa em $47 \%$ dos casos estudados, deficiente em $37 \%$ e regular em $16 \%$.

Observou-se uma grande defasagem entre as categorias da exposição do meato urinário externo para a limpeza, que foi deficiente em $90 \%$ das observações realizadas e, na limpeza, o procedimento foi defi.ciente em $80 \%$ dos casos, regular em $10 \%$ e bom em $10 \%$.

Quanto aos métodos de colheita $7 \%$ foram de cateterismo vesical, $30 \%$ de jato-médio colhido pelo profissional ou ocupacional e $63 \%$ de jato-médio colhido pela paciente.

Verificou-se que o método mais utilizado foi o de jato-médio colhido pela paciente. Das amostras colhidas por este método, $11 \%$ foram consideradas boas e $89 \%$ deficientes.

Das amostras colhidas em jato-médio pelos profissionais ou ocupacionais, $45 \%$ foram consideradas regulares, $33 \%$ boas e $22 \%$ deficientes.

As amostras colhidas por cateterismo vesical foram consideradas regulares.

Os cuidados prestados à paciente, após a colheita da amostra de urina, foram deficientes em $40 \%$, regulares em $37 \%$ e bons em $23 \%$ dos casos observados.

Das amostras de urina encaminhadas ao laboratório para serem inoculadas em meio de cultura apropriado, constatou-se que em $73 \%$ o método foi bom, em $17 \%$, regular e em $10 \%$, deficiente.

Os cuidados dispensados ao material foram deficientes em $43 \%$, regulares em $37 \%$ e bons em $20 \%$ dos casos estudados e, em relação ao ambiente, após a colheita, foram regulares em 37\%, bons em $33 \%$ e deficientes em $30 \%$ dos hospitais observados.

Verificou-se que, nesse trabalho, a enfermagem executou apenas $23 \%$ das colheitas e outros profissionais ou ocupacionais (bioquímicos, farmacêutico, técnicos ou auxiliares de laboratório e colhedores de material) executaram a maioria delas $(77 \%)$.

E imprescindivel que as pessoas responsáveis pela colheita de urina para cultura tenham conhecimentos sobre princípios científicos, anatômicos, fisiológicos, bem como habilidade manual; e que se atualizem constantemente sobre o assunto, cabendo à enfermeira responsável supervisionar todos os procedimentos pertinentes à referida técnica alertá-los sobre a importância do preparo e orientação da paciente a ser submetida à colheita de urina para cultura. 
Este estudo mostrou que há predominância do sexo feminino entre as pessoas que colhem a amostra de urina em mulheres. Isso parece demonstrar que, dentro da equipe de enfermagem, há uma preocupação em deixar um elemento do mesmo sexo para a colheita, devido a aspectos técnicos que envolvem a área genital feminina. As pacientes se sentem menos inibidas e ansiosas por se identificarem com as profissionais ou ocupacionais de seu sexo, havendo diminuição da ansiedade causada pela colheita de urina. DU GAS ${ }^{9}$ considera que o ato da micção é particular e o tema de eliminação vesical um assunto delicado, tanto para a profissional ou ocupacional quanto para a paciente, principalmente se forem de sexos opostos.

PAULA et alii ${ }^{24}$ ressaltam que devemos considerar, em relação ao ambiente: a privacidade, iluminação adequada e móveis apropriados para a acomodação da paciente e para a disposição do material.

FUERST et alii ${ }^{11}$ dizem que a assistência de enfermagem será incompleta, e menos do que profissional, se não for levado em consideração o meio ambiente proporcionado aos pacientes; que o ambiente pode ajudar ou prejudicar o bem-estar da paciente; e que, a enfermagem é, portanto, responsável em proporcionar ambiente seguro e confortável aos pacientes sob seus cuidados.

Nos hospitais observados, a condição das salas era regular ou deficiente, de acordo com o nosso sistema interpretativo, uma vez que a maioria das salas de colheita de urina é adaptada, não oferecendo condições ideais de atendimento. A equipe de enfermagem executa suas tarefas em salas cujas condições são regulares. Nos laboratórios a maioria dos profissionais ou ocupacionais trabalha em salas cujas condições são regulares ou deficientes, sendo minimas as salas em boas condições.

Verificou-se que a privacidade da paciente é pouco respeitada e as justificativas são a falta de roupa para proteger a mesma e o fato das salas serem adaptadas e sem portas. Na verdade, muitas vezes, o procedimento rotineiro faz com que os profissionais ou ocupacionais se esqueçam de que estão manuseando uma área delicada do corpo humano e que as pacientes sentem-se agredidas em seu pudor.

A iluminação, fator importante para o bom desempenho do procedimento em relação a visualização do meato uretral externo, é muitas vezes esquecida, assim como a ventilação do ambiente. Tais fatores poderiam ser minimizados se houvessem focos de luz e ventiladores. Ainda em relação ao material, observou-se, em algumas instituições, a existência de material básico para uma boa colheita, que não é usado, caracterizando isso o desconhecimento, por parte dos profissionais ou ocupacionais que atuam na colheita de amostras, de princípios minimos para um bom desempenho assistencial.

Em relação ao manuseio do material estéril, parece que, na maioria dos locais, os princípios de assepsia não foram aplicados, demonstrando a falta de conhecimentos do pessoal e a ausência de supervisão por parte 
das chefias. Nos ambulatórios, o manuseio do material estéril, por parte das auxiliares e atendentes de enfermagem, é bom. Sobre os laboratórios não se pode dizer o mesmo em relação ao pessoal de enfermagem, uma vez que existem auxiliares e atendentes de enfermagem cujos procedimentos são deficientes no que tange às técnicas assépticas; em relação aos demais profissionais e ocupacionais, as freqüências estão divididas entre as categorias boa e deficiente, sendo que $90 \%$ das auxiliares de laboratório demonstraram procedimentos deficientes; esse indice é preocupante, uma vez que os referidos profissionais e ocupacionais efetuaram $37 \%$ das colheitas para urocultura; tal fato é de relevante importância, pois a literatura demonstra que a inobservância das técnicas assépticas no cateterismo vesical é a principal fonte de graves infecções.

A identificação das pacientes se reveste de muita responsabilidade para que não haja troca de amostras e, conseqüentemente, falhas diagnósticas e propedêuticas. As instituições que possuem impresso próprio para identificação o fazem de forma completa, porque o próprio impresso obriga a pessoa que colhe a amostra a preenchê-lo corretamente, identificando de maneira eficaz a paciente e a amostra. Nas instituições em que não há impresso próprio são usados outros recursos, tais como: esparadrapo, fita gomada ou de crepe, ficando muito a desejar a identificação da amostra. Podemos verificar que nos ambulatórios a categorização é boa, tanto para a identificação da paciente quanto para a amostra; nos laboratórios há equilíbrio entre as categorias boa e regular para as referidas identificações.

Sobre a orientação oferecida à paciente, devemos ressaltar que as auxiliares de enfermagem dos ambulatórios deram boa orientação, enquanto que nos laboratórios esta foi regular. As atendentes, tanto dos ambulatórios quanto dos laboratórios, deram orientação regular. A orientação da maioria dos profissionais e ocupacionais que atuam nos laboratórios foi categorizada como regular, de acordo com o sistema interpretativo. A orientação da paciente é fundamental e deve ser completa quanto à identificação, hidratação, limpeza, constatação se é a primeira experiência da paciente e explicação minuciosa de todos os procedimentos que se desenrolarão durante a técnica; dessa forma, a paciente sentirá segurança, confiança, e irá colaborar durante a colheita de urina.

A posição da paciente para a limpeza da área periuretral foi boa em $47 \%$, porém a exposição do meato uretral externo foi deficiente em $90 \%$, e a limpeza deste e da área periuretral também foi processada de maneira deficiente em $80 \%$. Estes resultados parecem demonstrar ter havido orientação prévia dos funcionários que executam a técnica, mas acredita-se que a falta de conhecimentos sobre princípios científicos e a ausência de supervisão por parte dos profissionais responsáveis levaram a procedimentos deficientes como um todo, isto é, o início é correto mas deixam a desejar os passos subseqüentes em relação aos princípios assépticos a serem observados. 
As posiçōes mais utilizadas para a cateterização são o decúbito dorsal, a posição de litotomia, a ginecológica, embora haja pessoas que utilizam o decúbito lateral, com os joelhos da paciente fletidos e a perna superior mais próxima ao tórax que a inferior (DU GAS ${ }^{9}$ e OLIVEIRA ${ }^{23}$ ).

Nos hospitais observados, verificou-se que foi usada a posição ginecológica para a limpeza do meato uretral externo e da área periuretral, e a posição de pé para a auto-colheita. Constatou-se, também, que nos ambulatórios as auxiliares de enfermagem colocaram as pacientes em boa posição, enquanto que nos laboratórios usaram uma posição que foi categorizada como regular, para proceder à limpeza do meato e da área periuretral; $50 \%$ das atendentes de enfermagem, de ambos locais, colocaram as pacientes em boa posição, enquanto as outras $50 \%$ as posicionaram de forma incorreta, sendo o procedimento categorizado como deficiente. Os procedimentos executados pelos técnicos e auxiliares de laboratório se distribuiram entre as três categorias, com predominância para a categorização boa, enquanto que os executados pelos profissionais e ocupacionais denominados "outros" foram deficientes em $100 \%$ neste procedimento.

Em relação à exposição do meato uretral externo para limpeza adequada, viu-se que foi deficiente em $90 \%$; após um bom posicionamento, o passo seguinte seria expor o meato uretral externo e proceder à limpeza; no entanto, os profissionais e ocupacionais deixam de executar este procedimento. A literatura pertinente enfatiza que os pequenos lábios, localizados na região periuretral, devem ser afastados com os dedos indicador (ou médio) e polegar, com a finalidade de expor o meato urinário externo, posição esta que deverá ser mantida durante a limpeza e durante a colheita da amostra de urina, seja esta realizada por intermédio do jato-médio ou cateterismo vesical (DU GAS ${ }^{9}$, DUTRA et alii "1", FUERST et alii ${ }^{11}$, HOOD \& DINCHER ${ }^{14}$ e KING et alii ${ }^{16}$ ). Ficou evidenciado que apenas $25 \%$ das atendentes de enfermagem e $14,3 \%$ dos técnicos de laboratório procederam a uma boa exposição do meato uretral externo da paciente para limpeza da área; as atendentes de enfermagem mencionadas pertencem aos ambulatórios. Os procedimentos das auxiliares de enfermagem de ambos os locais e dos demais profissionais e ocupacionais foram categorizados como deficientes.

Em relação à limpeza do meato uretral e da área periuretral, a maior parte das limpezas foram executadas com movimentos aleatórios, de cima para baixo e vice-versa, sem a menor preocupação em evitar a contaminação do meato urinário com fezes, secreções vaginais ou com bactérias que permanecem nessa área; as bolas de algodão ou de gazes utilizadas para essa limpeza foram usadas em vários movimentos, sendo raramente trocadas. Estes procedimentos levam a crer que os profissionais e ocupacionais que executam a colheita desconhecem os principios científicos que devem ser utilizados durante a limpeza da área periuretral. 
O método de colheita da amostra de urina mais utilizado foi o jato-médio colhido pela própria paciente $(63 \%)$. Das amostras colhidas por este método, $89 \%$ foram consideradas deficientes, constatando-se que há falta de orientação efetiva para a auto-colheita de urina. A maioria dos profissionais e ocupacionais entregava o recipiente estéril à paciente, pedindo-lhe que se dirigisse ao sanitário, começasse a urinar e colhesse uma porção de urina no recipiente. Em alguns casos, foi fornecido um chumaço de algodão emhebido em solução anti-séptica para a paciente fazer a higiene dos genitais antes da colheita; houve casos em que o profissional colocava a paciente em posição ginecológica, executava a limpeza do meato uretral e após pedia à mesma para descer da mesa, entregando-lhe o frasco estéril para que fizesse a colheita de urina no sanitário. Estes procedimentos foram considerados deficientes. Nos laboratórios, apenas os técnicos utilizaram adequadamente este método e os procedimentos dos demais profissionais e ocupacionais foram deficientes.

A orientação é que a colheita de urina para cultura bacteriológica em mulheres seja realizada por meio do método de jato-médio, com a ajuda e orientação de um profissional ou ocupacional da equipe de enfermagem. A limpeza do meato uretral e da área periuretral deve ser executada com material estéril, observando-se a técnica asséptica. A amostra de urina deve ser colhida diretamente em frasco estéril, de boca larga, com a paciente deitada, sentada ou semi-sentada, sendo que o meato uretral deverá ficar exposto desde a limpeza até o final da colheita.

Em relação aos cuidados prestados às pacientes após os procedimentos, evidencia-se que foram deficientes em $40 \%$, regulares em $37 \%$ e bons em 23\%; talvez pela condição de serem pacientes de ambulatório, fiquem negligenciados os aspectos assistenciais sobre a sua segurança física ao descer da maca ou da mesa ginecológica. Quanto à orientação sobre dúvidas ou expectativas e retornos, quando dada, foi de forma incompleta.

Em relação à limpeza do meato uretral, se a paciente recebe um chumaço de algodão embebido em solução anti-séptica, para limpeza dos genitais, sem orientação, acaba empregando todo o chumaço de algodão de uma só vez, com movimentos aleatórios. Notou-se, também, ausência completa de orientação à paciente sobre os cuidados que deve ter com o frasco estéril, como posicioná-lo, como destampá-lo, onde e como segurar ou apoiar a tampa do frasco (em vários casos foi utilizado tubo de ensaio com tampa de algodão hidrófilo). Nestes casos, é previsivel que haja contaminação, partindo do pressuposto que a paciente, com raras exceçōes, conhece e faz uso de técnicas assépticas.

Observou-se, também, que as pacientes nem sempre colheram o jato-médio da micção porque, na verdade, quando foi pedida esta forma de colheita, não lhes foi explicado o que é jato-médio; infelizmente, grande parte delas parece desconhecer o termo utilizado e, por falta de orientação, a paciente contamina a boca do frasco, encostando-o na 
face interna das coxas, nos pelos pubianos ou nos pequenos e grandes lábios. Sobre a posição que a paciente deve assumir para este método de colheita, também nada lhe foi orientado; portanto, ela assume qualquer posição, desde as mais simples até as má.is desconfortáveis, porém, nenhuma correta.

Conforme os resultados, nos ambulatórios, as auxiliares de enfermagem prestaram bons cuidados às pacientes após a colheita de urina, mas os cuidados prestados pelas atendentes de enfermagem foram categorizados como regulares e deficientes. Nos laboratórios as auxiliares de enfermagem prestaram cuidados regulares e as atendentes de enfermagem, bons e regulares. Para os demais profissionais e ocupacionais esse procedimento concentrou-se nas categorias regular e deficiente.

Sabe-se que o tempo é um fator importante no crescimento das bactérias; o período de tempo que decorre entre a colheita de urina e sua semeadura deverá ser o mais curto possivel; quanto maior for o tempo decorrente entre a colheita da amostra de urina e o processamento bacteriológico, maior será o erro na determinação quantitativa por causa da proliferação bacteriana.

Para MILLER ${ }^{21}$ o ideal é que a urina seja encaminhada ao laboratório antes que tenham decorrido duas horas após a obtenção da amostra. Entretanto, tolera-se que a amostra seja encaminhada dentro do limite de duas horas, desde que mantida sob refrigeração $\left(4^{\circ} \mathrm{C}\right)$.

Verificou-se, neste estudo, que $66,7 \%$ das auxiliares de enfermagem fizeram bom encaminhamento da amostra de urina para o processamento bacteriológico e $33,3 \%$ procederam de forma regular; $25 \%$ das atendentes fizeram bom encaminhamento, $25 \%$ regular e $50 \%$ deficiente. Nos laboratórios, os profissionais e ocupacionais deram bom encaminhamento a $82,6 \%$ das amostras, regular a $13,1 \%$ e deficiente a $4,3 \%$.

Verificou-se, por meio das observações, que muitas salas utilizadas para a colheita da amostra de urina para cultura não dispõem de áreas para os cuidados que o material usado requer. Por outro lado, raras instituições utilizam soluçōes químicas adequadas na desinfecção do material utilizado.

Em alguns locais observou-se que os profissionais desprezavam urina das pacientes na pia de sala de colheita e, após, lavavam o material no mesmo local, apenas com água corrente. Estes procedimentos foram considerados deficientes, uma vez que contrariam os princípios básicos de higiene, tão importantes na área da saúde. Nos ambulatórios, os cuidados dispensados ao material, por parte das auxiliares de enfermagem, foram bons e, por parte das atendentes de enfermagem, regulares. Nos laboratórios o procedimento executado pelos profissionais e ocupacionais foi deficiente.

Quanto ao ambiente, poucos cuidados foram dispensados. Sabe-se que os responsáveis pela colheita de amostras devem proceder à limpeza e à ordem do ambiente, após utilizado, para proporcionar bem-estar, 
conforto e segurança aos pacientes. Os profissionais e ocupacionais devem ser orientados no sentido de cuidar do ambiente, para evitar o aparecimento de infecções. Nos ambulatórios, as auxiliares de enfermagem dispensaram bons cuidados ao ambiente e nos laboratórios, regulares.

A duração dos procedimentos de colheita da amostra de urina para cultura, tanto nos ambulatórios como nos laboratórios, foi concentrada no intervalo de 5 a menos de 10 minutos.

\section{CONCLUSÕES}

São as seguintes as conclusões, como respostas aos objetivos específicos:

- o laboratório de análises clínicas foi o local do hospital onde foram realizadas $87 \%$ das colheitas das amostras de urina para cultura bacteriológica; no ambulatório foram realizadas apenas $13 \%$ das colheitas;

- dos elementos que realizaram a colheita de urina, $37 \%$ eram auxiliares de laboratório, $23 \%$ técnicos de laboratório, $13 \%$ atendentes de enfermagem, $10 \%$ auxiliares de enfermagem e $17 \%$ outros (bioquímicos, farmacêuticos e colhedoras de material);

- quanto às condições das salas onde foram realizadas as colheitas de urina, $50 \%$ foram regulares, $37 \%$ deficientes e apenas $13 \%$ foram consideradas boas;

- o material utilizado para a realização da técnica foi considerado deficiente em $50 \%$, regular em $27 \%$ e bom em $23 \%$ das instituições;

- os procedimentos, quanto ao manuseio do material estéril, foram deficientes em $57 \%$ e bons em $43 \%$;

- quanto aos fatores que integram o preparo da paciente submetida à colheita de urina, sua identificação e a da amostra foram consideradas boas em $50 \%$, regulares em $43 \%$ e deficientes em $7 \%$; a orientação fornecida às pacientes sobre o procedimento da colheita da amostra de urina foi considerada regular em $67 \%$, deficiente em $23 \%$ e boa em $10 \%$; a posição em que a paciente foi colocada para a realização da limpeza do meato uretral externo foi boa em $47 \%$, deficiente em $37 \%$ e regular em 16\%; a exposição do meato uretral externo para limpeza foi deficiente em $90 \%$, boa em $7 \%$ e regular em $3 \%$; a limpeza do meato uretral externo foi deficiente em $80 \%$, bo: em $10 \%$ e regular em $10 \%$;

- o método mais utilizado para a colheita da amostra de urina para a cultura foi o jato-médio colhido pela paciente $(63 \%)$, seguido pelo jato-médio colhido pelo profissional ou ocupacional $(30 \%)$; o cateterismo vesical foi o método menos utilizado, verificado em apenas $7 \%$ dos casos;

- os cuidados prestados à paciente após a colheita de urina foram deficientes em $40 \%$, regulares em $37 \%$ e bons em $23 \%$; 
- os cuidados com a amostra colhida foram bons em $73 \%$, regulares em $17 \%$ e deficientes em $10 \%$;

- os cuidados dispensados ao material após a colheita foram deficientes em $43 \%$, regulares em $37 \%$ e bons em $20 \%$;

- os cuidados em relação ao ambiente em que foi colhida a urina foram regulares em $37 \%$, bons em $33 \%$ e deficientes em $30 \%$;

a duração dos procedimentos de colheita da amostra de urina para cultura, tanto nos ambulatórios quanto nos laboratórios de análise clínica, ficou concentrada no intervalo de 5 a menos de 10 minutos.

VALENTE, S. M. T. B. Study about collection of urine for bacteriologic culture. Rev. Esc. Enf. USP, São Paulo, 17(3):253-274, 1983.

This study was made in the City of São Paulo, in 30 hospitals with the objective of to identify and classify the procedures of collecting urine for bacteriologic study. The data's collect has been realized based on a record prepared for a systematic observation directly connected to a system interpretative of categories ("Good", "Fair" and "Poor") applled to all procedures. The results obtained have been presented in the tables distributed in the absolute end relative frequencies, grouped and classified by categories. The conclusions where in accordance to the specific objectives initially proposed and has been classified under the interpretative systems of the categories previously defined and adressed to the research.

\section{REFERENCIAS BIBLIOGRAFICAS}

1. ANGFraMt, E. L. S. et alil. Avaliaçăo da técnica de colheita de urina asséptica em mulheres. Rov. Bras. Enf., Rio de Janeiro, 28(1):60-4, jan./mar. 1975.

2. Influéncia da hidratação e da orientação de enfermagem na obtençăo de urina em jato com assepsia. Rev. Bras. Enf., Rio de Janetro, 27(4):472-9, out./dez. 1974.

3. BEESON, P. B. Case against the catheter. Amer. J. Med., New York, 24(1):1-3, Jan. 1958.

4. BERGer, H. M. Problemas no diagnóstico da infecção urinária: editorial. Rev. Assoe. Mod. R. G. Sul, Porto Alegre, 22(3/4):6-7, jul./dez. 1978.

5. BLANDY, J. P. Catheterization. Nurs. Mirror, London, 134(2):26-9, June 1979.

6. CLARCK, $R$. et alli. Infection control: a team approach that really works. Can. Nurse, Montreal, 74(11):16-9, Dec. 1978.

7. CLARKE, S. H. Investigation into methods of collection of urine for culture from men and women. Brit. Med. J., London, $2: 1491-3$, Nov. 1977.

8. DESAUTELS, R. E. Aseptic management of catheter drainage. N. Engl. J. Mod., Boston, 263(4):189-91, July 1960.

9. DU GAS, B. W...Enfermagem prática. 3. ed. Rio de Janeiro, Interamericana, 1977. p. $420-35$.

10. DUTRA, V. de $O$. et alli. Enfermagem em cardiologia. São Paulo, Sarvier, 1981. p. 91-2. 11. FUERST, E. V. et alli. Fundamentos de enfermasem. Rio de Janeiro, Interamericana,
1977. p. 35066 .

12. GUZE, L. \& BEESON, P. B. Observations on the reliability of safety of bladder catheterization for bacteriologic study of the urine. N. Fingl. J. Mod., Boston, 255 (10) :474-5, Sept. 1956.

13. HELMOLZ, H. F. Determination of the bacterial content of the uretra. J. Urol., Baltimore, 64(1):158-66, July 1950.

14. HOOD, G. H. \& DINCHER, J. R. Total patient care foundations and practice. 5. ed. St. Louls, Mosby, 1980. p. 479-98. 
15. KASS, E. H. Chemotherapeutic and antibiotic drugs in the management of infection of urinary tract. Am. J. Med., New York, 18(5):764-81, May 1955.

16. KING, E. M. et alii. Illustrated manual of nursing techniques. 2. ed. Philadelphia, Lippincott, 1981. p. 77-169.

17. KUNIN, C. M. et alil. Urinary-tract infections in school Children I - Prevalence of bacteriuria and associated urologic findings. N. Engl. J. Med., Boston, 266(25):1287-96, June 1962.

18. LAPIDES, $J$. et alii. Further observation on self catheterization. Am. Assoc. Genita. Urin. Surk., $67: 15,1975$.

19. LEVIN, J. The incidence and prevention of infection after urethral catheterization. Ann. Intern. Med., Philadelphia, 60(5):914-22, May 1964.

20. LITTLE, P. J. Urinary infection in pregnancy. Nurs. Times, London, 63(38)1266, Sept. 1967.

21. MILleR, O. et alii. Laboratório para o clínico. 4. ed. Rio de Janeiro, Atheneu, 1981. p. 127.

22. OLIVeIRA, D. A. \& GAMARSKI, J. Infeção urinária. Temas Med., São Paulo, 5(2): 33-52, fev. 1981.

23. OLIVEIRA, M. L. Estudo comparativo entre as posições lateral e dorsal no caterismo vesical da mulher. Enf. Novas Dimens., Såo Paulo, 1(5):257-65, 1975..

24. PAULA, N. S. de et ali1. Normas a serem observadas em procedimentos básicos de enfermagem. Rev. Esc. Enf. USP, São Paulo, 13(3):233-50, dez. 1979.

25. PYRAH, L. N. Control of pseudomonas infection in a urology ward. Lancet, London, 2(13):314-7, July, 1955.

26. SADI, A. et alii. Infecções urogenitais. Ars. Curandi, Såo Paulo, 10(11):4-7, nov. 1978. 
FICHA DE OBSERVAÇÃO SISTEMATICA PARA COLHEITA DA AMOSTRA DE URINA PARA CULTURA BACTERIOLOGICA

1. Nome do hospital

2. Data Número da observação

3. Local da colheita de urina ( ) Ambulatório ( ) Laboratório

4. Pessoa que faz a colheita:
4.1 ( ) Enfermeiro
4.2 ( ) Técnico de enfermagem
4.3 ( ) Auxiliar de enfermagem
4.4 ( ) Atendente de enfermagem
4.5 ( ) Técnico de laboratório
4.6 ( ) Auxiliar de laboratório
( ) Outra
Qual?

5. Sexo da pessoa que faz a coleta:
4.1 ( ) Feminino
4.2 ( ) Masculino

6. Duração do procedimento:

7. Procedimento observados

Sistema de avaliação

7.1 Preparo do ambiente e do material 7.1.1 Condições da sala de colheita

7.1.2 Material utilizado à colheita

7.1.3 Manuseio do material estéril

7.2 Preparo da paciente

7.2.1 Identificação

7.2.2 Orientação da paciente

7.2.3 Posição da paciente

7.2.4 Exposição da uretra

7.2.5 Limpeza da área

7.3 Métodos de colheita

7.3.1 Cateterismo vesical

7.3.2 Jato-médio, colhido pelo funcionário

7.3.3 Jato-médio, colhido pela paciente

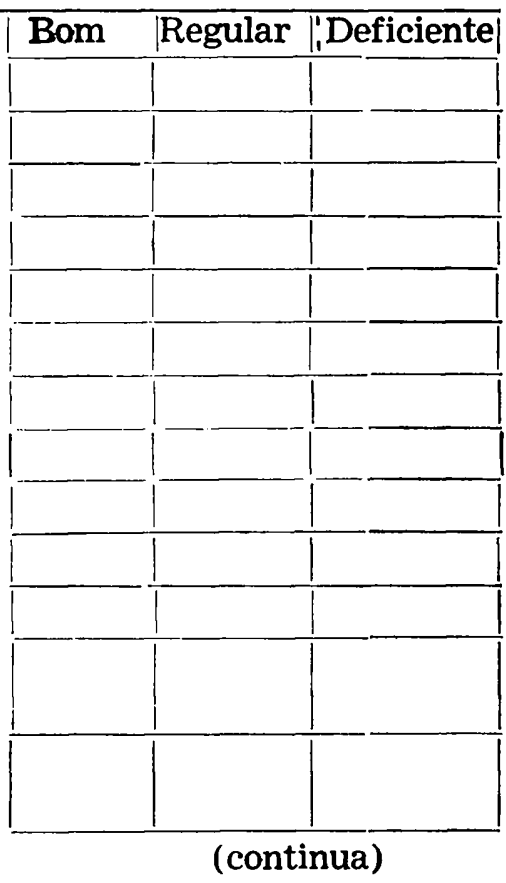


(continuação)

7.4 Cuidados após a colheita da urina

7.4.1 Cuidados com a paciente

7.4.2 Encaminhamento da amostra

7.4.3 Cuidados com o material utilizado

7.4.4 Cuidados com o ambiente

8. Outras ocorrências: 